\title{
MADRASAH ALIYAH DAN SEKOLAH MENENGAH KEJURUAN DALAM PERSEPKTIF EKONOMI ISLAM
}

\author{
Nurhadi \\ Kopertais XII Riau \\ alhadijurnal@gmail.com
}

\begin{abstract}
Formal Education Institutions that directly print productive age cadres are vocational madrasabs (MAK) and vocational high schools (SMK). The history and origins of MAK and SMK, that MAK is more oriented to religious education based on skills or skills as a means of living in the world. Whereas Vocational Schools almost certainly emphasize skills and skills. The contents of MAK's subjects are 70\% religious subjects, 70\% vocational subjects. Of the two MAK and SMK alumni who tend to study Islamic economics or courses in Islamic economics majors is $M A K$. Then $M A K$ and SMK, if viewed from Islamic economic principles that are more directed at strengthening religious teachings, so that they can be practiced and applied in the world of work, according to the author $M A K$ is more relevant and more profitable, both in the world and the hereafter. Especially if it is weighed by the theory of Islamic education and education philosophy that is oriented towards noble character and morality, the educational goals of Islamic economic perceptive $M A K$ are closer to perfect compared to SMK
\end{abstract}

Keywords: MAK, SMK, Perspective, Islamic Economics

\begin{abstract}
Abstrak : Lembaga Pendidikan Formal yang langsung mencetak kader-kader usia produksif adalah madrasah aliyah kejuruan (MAK) dan sekolah menengah kejuruan (SMK). Sejarah dan asal muasal MAK dan SMK, bahwa MAK lebih berorientasi pada pendidikan agama yang berbasis skill atau keterampilan sebagai bekal menjalani hidup di dunia. Sedangkan SMK hampir dipastikan lebih menonjolkan skill dan ketetampilan saja. Muatan-muatan mata ajar MAK 70\% mata ajar agama, SMK 70\% mata ajar kejuruan. Dari kedua alumni MAK dan SMK yang kecenderungan akan belajar ekonomi Islam atau kuliah jurusan ekonomi Syariah adalah MAK. Maka MAK dan SMK, jika ditinjau dari prinsip-prinsip ekonomi Islam yang lebih mengarah ke penguatan ajaran agama, sehingga bisa diamalkan dan diaplikasikan dalam dunia kerja, menurut penulis MAK lebih relevan dan lebih menguntungkan, baik dunia maupun akhirat. Apalagi jika ditimbang dengan teori filsafat pendidikan dan pendidikan Islam yang berorientasi pada budi pekerti yang luhur dan berakhlakul karimah, tujuan pendidikan MAK persepktif ekonomi Islam lebih mendekati sempurna diabandingkan SMK.
\end{abstract}

Kata Kunci: MAK, SMK, Persepktif, Ekonomi Islam 


\section{PENDAHULUAN}

Pendidikan merupakan sektor terpenting dalam mewujudkan manusia yang cerdas, beradab dan manusia seutuhnya sesuai dengan yang tersurat dalam UUD 1945 dan tujuan pendidikan nasional. Yang dalam hal ini salah satunya dapat dilaksanakan melalui pendidikan. Selanjutnya dalam Undang-Undang Sisdiknas dijelaskan bahwa pendidikan nasional berfungsi untuk mencerdaskan kehidupan bangsa melalui pengembangan kemampuan serta pembentukan watak dan peradaban bangsa yang bermartabat di tengah persaingan zaman. ${ }^{1}$ Seperti diketahui bahwa pendidikan merupakan usaha manusia untuk menumbuhkembangkan potensi-potensi bawaan, baik jasmani maupun rohani, sesuai dengan nilai-nilai yang ada dalam masyarakat dan kebudayaan. ${ }^{2} \mathrm{Hal}$ ini dapat dilihat dari kehidupan manusia sehari-hari baik dari cara berfikir, bersikap maupun bertindak yang semuanya dilandasi pada sejauh mana tingkat pendidikan yang mereka miliki karena dalam pendidikan tidak hanya terjadi proses transformasi penge-tahuan akan tetapi juga terjadi transformasi nilai. $^{3}$

Salah satu uapaya untuk merubah nasib seseorang ada ilmu, dizaman sekarang ilmu harus memiliki legalitas yaitu ijazah formal secara hukum, hal ini menjadi penyebab seseorang yang ingin merubah nasibnya mesti harus sekolah (belajar). Diantara sekian banyak lembaga pendidikan formal yang langsung mencetak kaderkader usia produksif adalah madrasah aliyah kejuruan (MAK) atau sekolah menengah kejuruan (SMK). Fakta dan realita membuktikan bahwa angkatan selevel pada sekolah tingkat dan menengah atas (SLTA/SMA) yang paling di minati oleh pemula dan pemuda siap kerja atau ready berwirausaha adalah alumni SMK dan MAK secara keseluruhan. Hal tersebut sangat mudah dijumpai dilapangan para usia kerja produktif muda rata-rata tamatan dan alumni SMK dan MAK.

Sebagaimana disebutkan diatas, bahwa pendidikan adalah agen utama suatu perubahan. Pendidikan harus mampu mewujudkan perubahan besar dalam tatanan

1Johar Maknun, "Pengembangan Sekolah Menengah Kejuruan (SMK) Boarding School Berbasis Keungulan Lokal", Direktori/FPTK/Jurusan Pendidikan Teknik Arsitektur, (Upi Edu: 196803081993031), 1-30, hlm. 1

${ }^{2}$ Fuad Ihsan, Dasar-Dasar Kependidikan (Jakarta : PT. Rineka Cipta, 2008), hlm. 1-2.

${ }^{3} \mathrm{H}$ M. Syamsudini, "Pendidikan Madrasah Dalam Lintas Sejarah Indonesia", Jurnal Turats, (36.91.149.11), 145-152, hlm. 1-2 
kehidupan masyarakat, baik ekonomi maupun sosial. Perubahan yang diharapkan dari pendidikan adalah perubahan yang mengarah kepada peningkatan kompetensi pelaku pendidikan, baik di kalangan pendidik, maupun peserta didik, secara financial maupun sosial. ${ }^{4}$ Masyarakat Indonesia sudah mulai menunjukkan semangat kewirausahaan. Menurut Menteri Koperasi dan UKM pada Juni 2018 menyatakan, jumlah pelaku mikro kecil dan menengah (UMKM) diperkirakan tumbuh menjadi 7\%, namun sampai saat Oktober 2018 baru mencapai 4,4 \% dari jumlah sekitar 265 Juta penduduk berdasarkan data BPS tahun 2018, yang pada dua tahun sebelumnya lebih sedikit yakni 3,1\% dan 2,1\%. ${ }^{5}$ Jumlah wirausahawan di Indonesia, tercatat pada Februari 2014, ada hanya berkisar 44,2 juta orang yang berusaha membuka lapangan kerja secara berdikari. Sementara, total penduduk bekerja di republik ini mencapai 118,1 juta orang. Bila dikaji lebih dalam lagi, wirausahawan di Indonesia terdiri dari jumlah penduduk yang berwirausaha secara mandiri sebanyak 20,32 juta orang; berwirausaha dibantu buruh tidak tetap 19,74 juta orang, dan berwirausaha dibantu buruh tetap 4,14 juta orang. Jumlah wirausahawan baru mencapai 1,56 persen dari total populasi. ${ }^{6}$ Sementara di tahun 2018 akhir baru kisaran 58,97 juta orang, maka kurang lebih 4,4\% dari jumlah penduduk Indonesia di tahun 2017 sejumblah 265 juta jiwa. ${ }^{7}$

Dunia lembaga pendidikan harus membangun kemandirian sekolah melalui kegiatan kewirausahaan atau bahasa yang dipersamakan yaitu wiraswasta, yaitu orang yang pandai atau berbakat mengenal produk baru, menentukan cara produksi baru, menyusun operasi untuk pengadaan produk baru, memasarkannya serta mengatur permodalan operasinya. Karakter diri seorang wirausahawan adalah memiliki watak berani, bersungguh-sungguh, dan mengerahkan segenap kemampuan dalam

${ }^{4}$ Muh. Ali Mukhtar dan Jejen Musfah, "Membangun Kewirausahaan di Sekolah". Journal for Integrative Islamic Studies Hikmatuna, Vo. 4 No. 2 (2018), 204-215, hlm. 205

${ }^{5}$ Maizal Walfajri dan Herlina Kartika, "Menkop UKM : Rasio wirausaha Indonesia sudah lebih dari 7\%". Kontan.co.id, (05 Juni 2018), https://peluangusaha.kontan.co.id/news/menkop-ukmrasio-wirausaha-indonesia-sudah-lebih-dari-7, diakses 3 Juli 2019.

'Ardiyan Mohammad. "Sistem Pendidikan Biang Kerok Indonesia Minimnya Wirausaha", Merdeka.com, (12 Juli 2014), https://www.merdeka.com/uang/sistem-pendidikan-biang-kerokindonesia-minim-wirausaha.html, diakses 3 Juli 2019.

${ }^{7}$ Maizal Walfajri dan Narita. "Jumlah pelaku UMKM di 2018 diprediksi mencapai 58,97 juta orang”, Kontan.co.id, (05 Oktober 2018), https://keuangan.kontan.co.id/news/jumlah-pelaku-umkmdi-2018-diprediksi-mencapai-5897-juta-orang, diakses 3 Juli 2019 
mencapai dan memenuhi tujuannya. ${ }^{8}$ Peraturan Menteri Pendidikan Nasional Nomor 13 Tahun 2007 tentang Standar Kepala Sekolah/madrasah menyebutkan bahwa setiap kepala sekolah/madrasah harus memiliki 5 (lima) kompetensi dasar, yaitu: kompetensi kepribadian, manajerial, supervisi, sosial, dan kewirausahaan. ${ }^{9}$ Kelima standar tersebut sangat sesuai dengan nilai-nilai etos kerja dalam ajaran Islam, apalagi di poin yang kelima, yaitu kewirausahaan, hal ini dapat dilihat dalam al-Qur'an surah al-Jumuah ayat 10 yang artinya: "apabila telah ditunaikan shalat, Maka bertebaranlah kamu di muka bumi; dan carilah karunia Allah dan ingatlah Allah banyak-banyak supaya kamu beruntung". ${ }^{10}$ Hal ini sesuai dengan Undang-Undang Republik Indonesia Nomor 20 Tahun 2003 Tentang Sistem Pendidikan Nasional Pasal 1 ayat 1. ${ }^{11}$ Senada dengan Peraturan Menteri Pendidikan Nasional Nomor 28 Tahun 2009 Tentang Standar Kompetensi Kejuruan Sekolah Menengah Kejuruan $(\mathrm{SMK}) /$ Madrasah Aliyah Kejuruan $(\mathrm{MAK}) .{ }^{12}$ Didukung dengan Peraturan Menteri Pendidikan Pendidikan dan Kebudayaan Republik Indonesia Nomor 70 Tahun 2013 Tentang Kerangka Dasar dan Struktur Kurikulum Sekolah Menengah Kejuruan $(\mathrm{SMK}) /$ Madrasah Aliyah Kejuruan (MAK). ${ }^{13}$

Setelah sah secara legal hukum keberadaan MAK yang menyaingi seniornya SMK, maka kedua sistem pendidikan tingkat atas ini memiliki keahlian sesuai dengan jurusannya masing-masing, namun yang jelasnya jurusan tersebut sudah pasti sangat dibutuhkan dimasyarakat, umumnya di kalangan pelaku ekonomi sosial. Terkait dengan kondisi tersebut, maka sekolah menengah kejuruan (SMK/MAK) memberikan alternatif solusi dengan memberikan bekal kompetensi yang terpakai di

${ }^{8}$ Depertemen Pendidikan dan Kebudayaan, Kamus Besar Bahasa Indonesia (Jakarta: Kemendikbud, 2010), hlm. 1197

${ }^{9}$ Muh. Ali Mukhtar dan Jejen Musfah, "Membangun Kewirausahaan di Sekolah", hlm. 205206

${ }^{10}$ Departemen Agama RI, Al-Qur'an dan Terjemahanya (Semarang: Toha Putra, 2015), hlm. 933

${ }^{11}$ Lembaran Negara Undang-Undang Republik Indonesia Nomor 20 Tahun 2003 Tentang Sistem Pendidikan Nasional Pasal 1 ayat 1, 1-26, hlm. 1

${ }^{12}$ Salinan Menteri Pendidikan Nasional Nomor 28 Tahun 2009 Tentang Standar Kompetensi Kejuruan Sekolah Menengah Kejuruan (SMK)/Madrasah Aliyah Kejuruan (MAK), hlm. 1-517.

${ }^{13}$ Salinan Peraturan Menteri Pendidikan Pendidikan dan Kebudayaan Republik Indonesia Nomor 70 Tahun 2013 Tentang Kerangka Dasar dan Struktur Kurikulum Sekolah Menengah Kejuruan/Madrasah Aliyah Kejuruan, hlm. 1-220. 
dalam kehidupan bermasyarakat. ${ }^{14}$ Baik Kecerdasan Intelektual, Emosional dan Spiritual, terutama lulusan MAK. ${ }^{15}$ Maka dalam artikel ini penulis hendak menjelaskan bagaimana tinjauan ekonomi Islam terhadap kedua pendidikan formal tersebut?.

\section{PEMBAHASAN}

\section{Sejarah Madrasah Aliyah Kejuruan (MAK)}

Madrasah pada dasarnya berasal dari bahasa Arab 'madrasah' yang artinya 'tempat belajar'. Sebagai tempat belajar, kata 'madrasah' dapat disamakan dengan kata 'sekolah'. Namun, dalam kerangka sistem pendidikan nasional keduanya berbeda. ${ }^{16}$ Sekolah dikenal sebagai lembaga pendidikan tingkat dasar dan menengah yang kurikulumnya menitikberatkan pada mata pelajaran umum, dan pengelolaannya berada di bawah naungan Departemen Pendidikan Nasional. Sedangkan madrasah dikenal sebagai lembaga pendidikan keagamaan tingkat dasar dan menengah yang, karenanya, lebih menitikberatkan pada mata pelajaran agama, dan pengelolaannya menjadi tanggungjawab Departemen Agama. ${ }^{17}$

Sebenarnya keberadaan madrasah di dunia Islam telah muncul sekitar abad ke-4/5 H (10/11 M), seperti munculnya madrasah-madrasah di Naisaphur Iran $( \pm$ $400 \mathrm{H})$ dan Madrasah Nidzamiyah di Baghdad $(457 \mathrm{H}),{ }^{18}$ keberadaan madrasah di Indonesia baru dijumpai pada awal abad 20. Dengan demikian, kemunculan madrasah di tanah air tidak memiliki hubungan langsung dengan keberadaan

${ }^{14}$ Yoga Pramono, "Kajian Kebutuhan dan Penyediaan Sekolah Menengah Kejuruan di Kabupaten Rembang", Tesis Master (Semarang: Program Pasca Sarjana Magister Teknik Pembangunan Wilayah dan Kota Universitas Diponegoro, 2009), hlm. v

${ }^{15}$ Agus Saefudin, Smk: Sekolah Mencetak Kuli dan Pengangguran (Sebuah Kritik dan Solusi Arah Kebijakan Sekolah Menengah Kejuruan), Makalah Master (Semarang: Program Pascasarjana Program Studi Manajemen Pedidikan Konsentrasi Kepengawasan Sekolah Universitas Negeri, 2015), hlm. 10

${ }^{16}$ H M. Syamsudini, "Pendidikan Madrasah", hlm. 3

${ }^{17}$ Mohammad Kosim, "Madrasah Di Indonesia (Pertumbuhan dan Perkembangan)", Jurnal Tadris, Vo. 2. No 1. (2007), 41-57, hlm. 42

${ }^{18}$ Azyumardi Azra, Pendidikan Islam; Tradisi dan Modernisasi Menuju Millenium Baru (Jakarta: Logos, 1999), hlm. vii-viii; lihat juga Ahmad Syalabi, Sedjarah Pendidikan Islam, terj. Muchtar Jahja dan Sanusi Latief (Jakarta: Bulan Bintang, 1973), hlm. 109-112; lihat juga George Makdisi, The Rise of Colleges: Institutions of Learning in Islam and The West (Edinburg : Edinburg University Press, 1981), hlm. 51-52; lihat juga Hasan Asari, Menyingkap Zaman Keemasan Islam; Kajian atas Lembaga-Lembaga Pendidikan (Bandung: Mizan, 1994), hlm. 44- 81. 
madrasah di era klasik. ${ }^{19}$ Beberapa penulis sejarah pendidikan Islam di Indonesia menyebut dua peristiwa penting yang melatarbelakangi munculnya madrasah di Indonesia, yaitu kolonialisme Belanda dan gerakan pembaharuan Islam. ${ }^{20}$

Kemudian lahirlah Kementerian Agama melalui Ketetapan Pemerintah Nomor 1/SD/1946, tanggal 3 Januari 1946 buah hasil dari usulan BP KNIP14. ${ }^{21}$ Sejak terbentuknya kementerian ini, segera dilakukan upaya-upaya lebih serius untuk memantapkan keberadaan pendidikan Islam, temasuk madrasah. ${ }^{22}$

Pada tahun 1950, tepatnya tanggal 5 April 1950, pemerintah mengesahkan Undang-Undang Nomor 4/1950 (Jo Undang-Undang Nomor 12/1954) tentang Dasar-Dasar Pendidikan dan Pengajaran di Sekolah. ${ }^{23}$ Tahun 1975, tepatnya tanggal 24 Maret 1975, dikeluarkan Surat Keputusan Bersama (SKB) Nomor 6/1975 dan Nomor 037/U/1975 antara Menteri Agama, Menteri Pendidikan dan Kebudayaan, dan Menteri Dalam Negeri tentang Peningkatan Mutu Pendidikan pada Madrasah. ${ }^{24}$ Dalam undangundang ini, tujuan pendidikan nasional diarahkan untuk "Membentuk manusia susila yang cakap dan warga negara yang demokratis serta bersusila serta bertanggungjawab tentang kesejahteraan masyarakat dan tanah air". ${ }^{25}$

Berlandaskan Keputusan Menteri Agama Nomor 73/1987, pemerintah membuka program khusus keagamaan di Madrasah Aliyah, yang dikenal dengan Madrasah Aliyah Program Khusus (MAPK). ${ }^{26}$ Program ini sebagai upaya untuk “menyempurnakan" kurikulum hasil SKB tiga menteri 1975, utamanya pada Madrasah Aliyah Program Pilihan IlmuIlmu Agama. Muatan kurikulum program

${ }^{19}$ H M. Syamsudini, "Pendidikan Madrasah", hlm. 4

${ }^{20}$ Maksum, Madrasab; Sejarah dan Perkembangannya (Jakarta: Logos, 1999), hlm. 81-82; lihat juga Azyumardi Azra, Pendidikan Islam, hlm. 36-38; lihat juga Azyumardi Azra, Pendidikan Islam, hlm 97-102; lihat juga Haidar Putra Daulay, Historisitas dan Eksistensi Pesantren Sekolah dan Madrasah (Yogyakarta: Tiara Wacana, 2001), hlm. 63-64 ; lihat juga Karel A. Steenbrink, Pesantren Madrasah Sekolab; Pendidikan Islam dalam Kurun Moderen (Jakarta: LP3ES, 1994), hlm. 26-29; lihat juga Abdurahman Assegaf, Politik Pendidikan Nasional; Pergeseran Kebijakan Pendidikan Agama Islam dari Praproklamasi ke Reformasi (Yogyakarta: Kalam Mulia, 2005), hlm. 188-189.

${ }^{21}$ Karel A. Steenbrink, Pesantren Madrasah Sekolah, hlm. 462-463.

${ }^{22}$ Mohammad Kosim, "Madrasah Di Indonesia", hlm. 47; lihat juga H M. Syamsudini, "Pendidikan Madrasah", hlm. 8

${ }^{23}$ Djumhur dan Danasuparta, Sedjarah Pendidikan (Bandung Djakarta: Tjerdas, 1961), hlm. 161; lihat juga Mohammad Kosim, "Madrasah Di Indonesia", hlm. 51

${ }^{24}$ Maksum, Madrasah, Zakiyah Darajat dalam Pengantar, hlm. vii-xiii; lihat juga H M. Syamsudini, "Pendidikan Madrasah", hlm. 12

${ }^{25}$ H M. Syamsudini, "Pendidikan Madrasah", hlm. 9

${ }^{26}$ H M. Syamsudini, "Pendidikan Madrasah", hlm. 15 
MAPK didominasi materi agama dengan perimbangan ; 70\% agama dan 30\% umum, berbanding terbalik dengan muatan kurikulum MA. ${ }^{27}$

Ditetapkanya Undang-Undang Sisdiknas Nomor 2/1989 mengubah secara signifikan posisi madrasah dalam sistem pendidikan nasional. Madrasah tidak lagi sebagai lembaga pendidikan keagamaan, melainkan menjadi sekolah umum berciri khas agama Islam. Melalui UU tersebut, yang kemudian diikuti lahirnya sejumlah PP dan keputusan di bawahnya, posisi madrasah dijelaskan pada SK Mendikbud Nomor 489/U/1992 tentang Sekolah Menengah Umum, ${ }^{28}$ menyatakan bahwa Madrasah Aliyah adalah Sekolah Menengah Umum yang berciri khas agama Islam yang diselenggarakan oleh Departemen Agama (pasal 1 ayat 6). ${ }^{29}$

Menurut Muhammad Kosim sebagaimana dikutip dalam A. Malik Fadjar, pengakuan madrasah sebagai sekolah umum berciri khas Islam merupakan wujud budaya simpatik jati diri budaya bangsa yang berakar pada peradaban "Bhinneka Tunggal Ika". ${ }^{30}$ Azyumardi Azra mengatakan, pengakuan tersebut menunjukkan bahwa secara perlahan namun pasti, dikotomi antarmadrasah dan sekolah umum mulai pudar. ${ }^{31}$ Sedangkan menurut Maksum, pengakuan tersebut dapat ditafsirkan sebagai upaya melakukan "integrasi" pendidikan Islam ke dalam sistem pendidikan nasional. Hal ini terlihat dari beberapa indikasi berikut; pertama, pendidikan agama menjadi salah satu mata pelajaran wajib dalam setiap jenis, jenjang, jalur pendidikan. ${ }^{32}$ Kedua, dalam sistem pendidikan nasional, madrasah dimasukkan ke dalam katagori pendidikan jalur sekolah. Jika sebelumnya terdapat dualisme antara sekolah dan madrasah, maka melalui kebijakan tersebut dapat dikatakan bahwa madrasah adalah sekolah umum berciri khas agama Islam. Ketiga, kendati madrasah termasuk ke

\footnotetext{
${ }^{27}$ Ketika Menteri Agama dijabat Munawir Syadzali. Lihat Mohammad Kosim, "Madrasah Di Indonesia", hlm. 53

${ }^{28}$ SK Mendikbud ini dikeluarkan sebagai tindak lanjut dari PP Nomor 29/1990 tentang Pendidikan Menengah, 1-20.

${ }^{29}$ SK Mendikbud Nomor 489/U/1992 selanjutnya ditindaklanjuti dengan Keputusan Menteri Agama Nomor 370/1993 tentang Madrasah Aliyah, 1-17.

${ }^{30}$ A. Malik Fadjar, Madarsah dan Tantangan Modernitas (Bandung : Mizan, 1999), hlm. 15

${ }^{31}$ Azyumardi Azra, Paradigma Baru Pendidikan Nasional; Rekonstruksi dan Demokratisasi (Jakarta : Kompas, 2002), hlm. 71.

${ }^{32}$ H M. Syamsudini, "Pendidikan Madrasah", hlm. 16
} 
dalam jalur pendidikan sekolah, pemerintah masih memberikan peluang untuk mengembangkan madrasah dengan jurusan khas keagamaan. ${ }^{33}$

Setelah mengakui madrasah sebagai sekolah umum berciri khas Islam, UU Sisdiknas Nomor 2/1989 masih mengakomodasi keberadaan lembaga pendidikan keagamaan sebagai salah satu jenis pendidikan menengah (pasal 15 ayat 2). ${ }^{34}$ Dan sesuai PP Nomor 29/1990 (pasal 11 ayat 2), "Tanggungjawab pengelolaan sekolah menengah keagamaan dilimpahkan oleh Menteri (Pendidikan dan Kebudayaan) kepada menteri Agama". Maka, sebagi tindak lanjut peraturan di atas Menteri Agama, berdasar KMA Nomor 371/1993, mendirikan sekolah menengah keagamaan dengan nama Madrasah Aliyah Keagamaan (MAK). ${ }^{35}$ Sebagai lembaga pendidikan keagamaan, muatan kurikulum MAK agak berbeda dengan MA. Kurikulumnya berdasar KMA Nomor 374/1993 tentang Kurikulum Pendidikan Menengah Keagamaan lebih didominasi materi keagamaan $( \pm 70 \%)$. Dengan prosentase materi agama yang dominan, maka MAK sesungguhnya merupakan "kelanjutan" dari program MAPK yang telah dirintis tahun 1987 (oleh Menteri Agama Munawir Syadzali). Hanya, jangkauan MAK lebih luas dibanding MAPK. ${ }^{36}$

Kehadiran UU Sisdiknas Nomor 20/2003 semakin memperkuat posisi madrasah sebagaimana telah dirintas dalam UU Sisdiknas Nomor 2/1989. Di antara indikatornya adalah penyebutan secara eksplisit madrasah yang selalu bersanding dengan penyebutan sekolah, yang hal ini tak ditemukan dalam undang-undang sebelumnya. ${ }^{37}$ Beberapa pasal misalnya Pasal 18 ayat 3: Pendidikan menengah berbentuk Sekolah Menengah Atas (SMA), Madrasah Aliyah (MA), Sekolah

\footnotetext{
${ }^{33}$ Mohammad Kosim, "Madrasah Di Indonesia", hlm. 55; lihat juga Maksum, Madrasah, hlm. 159-160.

${ }^{34}$ Berbunyi: "Pendidikan menengah terdiri atas pendidikan umum, pendidikan kejuruan, pendidikan luar biasa, pendidikan kedinasan, dan pendidikan keagamaan". Isi undang-undang ini kemudian ditindaklanjuti dengan PP Nomor 29/1990 tentang Pendidikan Menengah. Pada bab I pasal 1 ayat 4 dijelaskan bahwa pendidikan menengah keagamaan adalah pendidikan pada jenjang menengah yang mengutamakan penguasaan pengetahuan khusus siswa tentang ajaran agama yang bersangkutan.

${ }^{35} \mathrm{H}$ M. Syamsudini, "Pendidikan Madrasah", hlm. 18

${ }^{36}$ Mohammad Kosim, "Madrasah Di Indonesia", hlm. 56

${ }^{37}$ Anita Listiara dan Asmadi Alsa, "Esensi Bersekolah bagi Siswa Berisiko di Sekolah Menengah Kejuruan (SMK)”, Jurnal Psikologi, Vol. 38, No. 2, (2011), 164-175, hlm. 165
} 
Menengah Kejuruan (SMK), Madrasah Aliyah Kejuruan (MAK) atau bentuk lain yang sederajat. ${ }^{38}$

Di samping itu, undang-undang pendidikan yang baru juga mengakomodasi pendirian madrasah "baru" yang dalam undang-undang sebelumnya tidak dikenal, yaitu Madrasah Aliyah Kejuruan (MAK). Keberadaan MAK ini menunjukkan kesungguhan pemerintah untuk "benar-benar" menyetarakan madrasah dan sekolah. Dengan demikian, jika di sekolah menengah ada SMK, maka di madrasahpun sama, ada MAK. Jika diperhatikan dalam prakteknya Madrasah Aliyah Kejuruan (MAK) berbentuk satuan pendidikan formal yang setara / sederajat dengan SMA/SMK dan MA. Madrasah Aliyah Kejuruan (MAK) dikelola dan dibina oleh Departemen Agama (Depag). Dalam hal mata pelajaran yang diberikan kepada siswa Madrasah Aliyah Kejuruan (MAK) sama seperti pada siswa Sekolah Menengah Kejuruan (SMK). Daftar nama jurusan yang diselenggarakan Madrasah Aliyah Kejuruan (MAK) pun sama dengan SMK. ${ }^{39}$ Namun saat ini belum banyak Madrasah Aliyah Kejuruan (MAK) yang menyelenggarakan berbagai macam jurusan sebagaiman yang telah dilaksanakan olek Sekolah Menengah Kejuruan (SMK). Hal ini menunjukkan bahwa pemerintah (kemenag) belum sungguh-sungguh dalam realisasi Peraturan Menteri Agama RI Nomor 60 tahun 2015 di lapangan, sebagai bukti sampai saat ini setelah beberapa tahun undang-undangnya disahkan Madrasah Aliyah Kejuruan masih belum terlalu kelihatan. ${ }^{40}$

${ }^{38}$ Ibid. lihat juga Peraturan Menteri Agama RI Nomor 60 tahun 2015 tentang Perubahan atas Peraturan Menteri Agama RI Nomor 90 tahun 2013 tentang Penyelenggaraan Pendidikan Madsrasah, hlm. 1-16.

${ }^{39}$ Harun, "Mengenal Madrasah Aliyah (MA) Dan (MAK)", harunarcom.blogspot.com, (4 Juli 2019), http://harunarcom.blogspot.com/2014/06/mengenal-madrasah-aliyah-ma-dan-mak.html, diakses 3 Juli 2019.

${ }^{40}$ Mohammad Kosim, "Madrasah Di Indonesia", hlm. 57; lihat juga H M. Syamsudini, "Pendidikan Madrasah", hlm. 19 


\section{Asal Muasal Sekolah Menengah Kejuruan (SMK) Sampai dari Masa ke Masa}

Pendidikan di Indonesia berawal dari pendidikan berbasis keagamaan yang di selenggarakan oleh para pemuka dan penyabar agama Hindu, Budha,dan Islam. Pada zamannya, mereka telah mengembangkan sistem pendidikan yang relatif "tersruktur" dari segi isi maupun tingkat-tingkatnya. Namun sistem pendidikan dalam bentuk sekolah atau menyerupai sekolah sekarang baru dimulai pada abad ke-16. Sekolah pertama di Indonesia didirikan oleh penguasa Portugis di Maluku, Altonio Galvano, pada tahun 1536 berupa sekolah seminari untuk anak-anak dari pemuka pribumi. ${ }^{41}$

VOC mendirikan sekolah pertama di Ambon pada tahun 1607, disusul kemudian di Pulau Banda (1622), dipulau Lontar (1923), dan di Pulau Roen(1927), semuanya di kawasan Maluku yang kaya akan rempah-rempah dan menjadi sasaran awal misi VOC. Sekolah-sekolah tersebut pada dasarnya bertujuan untuk penyebaran agama Kristen . Diluar wilayah Ambon, VOC mendirikan juga sekolah di Jakarta(1617)yang menjadi Sekolah Batavia(Bataviaase School) pada tahun 1622; Sekolah Warga Masyarakat (Burgerschool) tahun 1630, Sekolah Latin (Latijnse School) tahun 1642, dan Sekolah Cina(Chinese School) tahun 1737. Sekolah yang berorientasi "Kejuruan" yang didirikan pertamakali pada zaman VOC adalah Akademi Pelayaran (Academie der Marine) pada tahun 1743 tetapi ditutup kembali pada tahun $1755 .^{42}$

Ketika kekuasaan VOC berakhir pada penghujung abad ke-18 pendirian sekolah-sekolah dilanjutkan oleh Pemerintah Hindia Belanda yang berdasarkan atas keturunan, bangsa, dan status sosial. Sekolah Pertama untuk anak-anak Eropa dibuka di Jakarta pada 1817, kemudian menyusul berbagai sekolah lainnya. Akan tetapi, setelah lebih dari dua abad berkuasa sejak zaman VOC, baru pada tahun 1853 Belanda mendirikan sekolah kejuruan, yaitu Ambachts School van Soerabaia (Sekolah Pertukangan Surabaya) yang diperuntukan bagi anak-anak Indo dan Belanda, disusul

\footnotetext{
${ }^{41} Y u l i$ Setiawan, "Mengenal Sejarah Pendidikan Kejuruan di Indonesia", Psmk.kemdikbud.go.id, (31 Mei 2016), http://psmk.kemdikbud.go.id/konten/1614/mengenal-sejarah-pendidikan-kejuruandi-indonesia, diakses 4 Juli 2019.

${ }^{42}$ Ibid.
} 
kemudian oleh sekolah serupa di Jakarta pada 1856. ${ }^{43}$ Kedua sekolah ini diselenggarakan oleh swasta. Baru pada tahun 1860, Pemerintah Hindia Belanda mengusahakan Sekolah Pertukangan di Surabaya untuk golongan Eropa. Bagi anakanak Pribumi, hingga saat itu belum ada sekolah serupa. Di luar Akademi Pelayaran yang didirikan tahun 1743, Sekolah Pertukangan di Surabaya yang berdiri pada tahun 1853 itulah sebagai sekolah kejuruan pertama di Indonesia. Bila sekolah ini menjadi patokan, maka hingga sekarang sekolah kejuruan di Indonesia telah berusia satu setengah abad. ${ }^{44}$

Pendidikan kejuruan bertujuan untuk mengembangkan keterampilan tertentu pada siswa sehingga dengan keterampilan yang dimilikinya, para siswa kelak sebagai warga negara akan turut mengambil bagian untuk meningkatkan harga diri dan martabat bangsa sebagai bangsa yang berbudaya dan beradab. Di zaman yang lampau, justru falsafah pendidikan dalam aspek ajaran moralnya jauh lebih menonjol daripada aspek kejuruannya. Pendidikan kejuruan sebagai suatu sistem, sesungguhnya baru dikembangkan sungguh-sungguh sejak perang dunia II. ${ }^{45}$ Pada zaman Belanda dan Jepang SMK ada beberapa model, SMK Kewanitaan, SMK Teknik dan SMK Pertanian juga SMK Perdagangan. ${ }^{46}$ Kemudian pada masa PELITA I, II dan III maka SMK sudah bertambah dengan SMK Perternakan dan SMK Pariwisata, sedangkan PELITA IV pendidikan SMK diarahkan pada sektor Usaha dan Industri. ${ }^{47}$

Pada PELITA V pendidikan SMK meniti beratkan pada keterampilan. Disahkannya UU No. 2/1989, PP. No. 28/1990 dan PP. No. 29/1990 adalah bahwa mulai tahun 1991/1992 telah dilakukan perubahan bentuk bagi 81 SMKTP (yaitu 60 ST dan 21 SKKP) menjadi SMP, dilanjutkan pada tahun 1992/1993 dengan perubahan bentuk bagi 106 SMKTP lainnya. Dengan demikian massih ada 73

\footnotetext{
${ }^{43}$ Novriza bin Muslim, "Riwayat Sekolah Menengah Kejuruan", Novrizalbinmuslim.wordpress.com, (1 Oktober 2014), https:/ / novrizalbinmuslim.wordpress.com/2014/10/01/riwayat-sekolah-menengah-kejuruan/, diakses 4 Juli 2019.

${ }^{44}$ Yuli Setiawan, "Mengenal Sejarah Pendidikan Kejuruan di Indonesia".

${ }^{45}$ Arie Wibowo Khurniawan, dkk., SMK: Sekolah Menengab Kejuruan dari Masa ke Masa (Jakarta: Direktorat Jenderal Pendidikan Dasar dan Menengah Kementerian Pendidikan dan Kebudayaan Republik Indonesia Kompleks Kementerian Pendidikan dan Kebudayaan RI, 2016/2018), hlm. 10

${ }^{46} \mathrm{Ibid} .$, hlm. 13-25

${ }^{47}$ Ibid., hlm. 26-74
} 
SMKTP yang perlu dipelajari eksistensinya (apakah akan dialihfungsikan menjadi SMP atau SLTA Kejuruan). ${ }^{48}$

Tercatat penambahan jumlah SMKTA Kejuruan dalam kurun waktu empat tahun tersebut adalah sebanyak 47 sekolah, terdiri dari: 5 STM, 1 SMT, 1 SMT Grafika, 2 SMT Kimia, 3 SMT Pertanian, 28 SMEA, 2 SMKK, 3 SMPS, 1 SMIK, dan 1 SMSR. Ke 47 sekolah tersebut, sebanyak 20 sekolah merupakan pendirian UPT baru dengan fasilitas melalui bantuan ADB Loan 675-INO untuk sekolah pertanian, Loan 715-INO untuk sekolah teknologi, dan Loan 574- INO untuk sekolah nonteknologi. Selebihnya, 5 sekolah merupakan hasil penegerian dan 22 sekolah hasil alih fungsi SPG/SGO. ${ }^{49}$

Pendidikan PJP mencakup rentang waktu 25 tahun atau lima Repelita. PJP I berlangsung mulai Pelita I (1969/1970-1973/1974) sampai dengan Pelita V (1988/1989-1993/1994). PJP II dimulai sejak Pelita VI (1993/1994-1997/1998) yang saat itu direncanakan untuk sampai Repelita X (2017/2018). Akan tetapi pada tahun 1998 terjadi gerakan reformasi yang menyebabkan pendekatan pembangunan berdasarkan babak-babak lima tahunan terhenti, sehingga pada sekitar tahun 1990-an dikenal dengan istilah "pembangunan nasional tanpa Repelita". 50

Sekolah Menengah Kejuruan yang merupakan salah satu sub-sistem dari sistem pendidikan nasional, sesuai dengan ketentuan pada Undang-Undang No. 2 tahun 1989 tentang Sistem Pendidikan Nasional, dan mempunyai tujuan utama untuk menyiapkan peserta didik terutama untuk dapat bekerja pada bidang tertentu -adalah salah satu jenis dan jenjang pendidikan yang mendapatkan perhatian utama sesuai dangan amanat GBHN 1993 dimaksud. Berbagai kajian dilakukan pada tahun terakhir Pelita V sebagai bahan dasar untuk memasuki Pelita VI. ${ }^{51}$

SMK dar masa ke masa selalu membangun dan memperluas pendidikan teknik dan kejuruan dengan dukungan dana APBN dan pinjaman luar negeri untuk memenuhi kebutuhan pembangunan yang semakin besar. Misalnya, pada akhir Pelita II setiap tahun diproyeksikan untuk dihasilkan 22.500 juru teknik (tradesmen).

\footnotetext{
${ }^{48}$ Ibid., hlm. 77

${ }^{49}$ Ibid., hlm. 78

${ }^{50}$ Ibid., hlm. 83

${ }^{51}$ Ibid., hlm. 85
} 
Menjabarkan piramida tenaga kerja untuk sektor industri, bisnis, dan jasa ke dalam program-program pendidikan teknik dan kejuruan. Mengembangkan Kurikulum SMK 1976 yang merupakan kurikulum pertama yang dibakukan untuk menggantikan Kurikulum sementara tahun 1974. Membangun 2 Instalasi Pendidikan Teknik (IPT), 6 Proyek Perintis STM Pembangunan 4 tahun dengan jurusan BELMO, dan 9 Balai Latihan Pendidikan Teknik (BLPT) yang menjadi tempat praktik sejumlah STM di sekitarnya, dan 2 Fakultas Kejuruan Teknik (FKT) di IKIP Padang dan Yogyakarta. Membangun PPPG Teknologi (TTUC) Bandung dan PPPG Kejuruan (VTUC) Jakarta. Meningkatkan mutu 80 STM, 100 SMEA Pembina, dan 45 SKKA; membangun 4 SMT Pertanian, 6 SMTK, 4 SMIK, 8 SMPS, 8 SMKI. Mengubah nomenklatur sekolah menengah kejuruan dengan mengikuti hukum "DM", misalnya SKKA menjadi SMKK, STM menjadi SMT, Kokar menjadi SMKI, SPIK menjadi SMIK, SMInd menjadi SMM, SPSA menjadi menjadi SMPS, SFMA menjadi SMF. ${ }^{2}$

Menangani tenaga kependidikan kejuruan sebagai unsur pokok pendidikan melalui inventarisasi dan analisis jumlah dan mutu/kualifikasi yang dibutuhkan sesuai dengan kurikulum yang berlaku. Langkah ini belum pernah dilakukan sebelumnya. Inventarisasi kemampuan LPTK dalam memasok guru kejuruan dibandingkan dengan kebutuhan. Menurunkan konsep terobosan supaya program-program SMK berjalan, sambil meningkatkan mutu guru yang ada (in-service training) maupun mendidik guru baru (pre-service training) melalui program D-III Guru Kejuruan dengan sistem lapis untuk memenuhi kebutuhan akan guru sebanyak 3.500 orang saat itu. Program ini dilakukan melalui Ikatan Dinas. Mendirikan sejumlah PPPG lingkup kejuruan yang baru serta meningkatkan fungsi dan peranan PPPG yang telah ada untuk menjadi kelompok pemikir (think thank) dalam pengembangan, perencanaan, dan operasionalisasi seluruh aspek pendidikan kejuruan di Indonesia. Tugas mendesak saat itu adalah menangani langsung pendidikan dan pelatihan guru yang ada dan calon-calon guru, melaksanakan program D-III GK bekerjasama dengan LPTK terdekat dan Politeknik Mekanik Swiss-ITB/POLMAN-Bandung. Melanjutkan program-program pembangunan sekolah-sekolah kejuruan sesuai

${ }^{52}$ Ibid., hlm. 92-93 
dengan sasaran-sasaran Pelita bekerjasama dengan ADB, Pemerintah Swiss, Australia, Belanda, Perancis, dan lain-lain. ${ }^{53}$

Pada akhir Pelita III terdapat 274 SLTP Kejuruan yang terdiri atas 194 ST dan 80 SKKP, serta 559 SLTA Kejuruan). Merehabilitasi 64 SLTP Kejuruan Negeri dan mengkonsolidasikan 210 sekolah jenis lainnya. Mengembangkan SKK (Sekolah Keterampilan Kejuruan) 4 tahun di 10 lokasi. Melakukan penyesuaian 11 jurusan di SLTP Kejuruan dan 61 jurusan di SLTA Kejuruan. Mengembangkan SMK yang membuka program kejuruan teknik dan non-teknik dibawah satu atap, yaitu SMK Kartini Batam, disusul dengan STM Manna di Bengkulu dan STM Dumai. Mengembangkan "pola asuh" dalam pendirian sekolah kejuruan yang melibatkan industri dan pemerintah daerah. Menjabarkan dan melaksanakan Kurikulum 1984 SMK yang menghasilkan 97 program studi. Meningkatkan daya tampung 145 STM Negeri, 277 SMEAN, 97 SMKK/SMTK, dan menambah fasilitas 23 SMT Pertanian. Menyelesaikan pembangunan PPPG Teknologi Medan dan Malang, PPPG Kejuruan di Jakarta, PPPG Kesenian di Yogyakarta, dan PPPG Pertanian di Cianjur. Mengangkat 10.000 guru baru untuk sekolah kejuruan, dan mengembangkan "Pola Mentawai" dalam rekrutmen calon guru dan penempatannya. ${ }^{54}$

Melakukan alih fungsi SLTP Kejuruan (ST, SKKP) menjadi SMP/SLTP Umum. Meskipun saat UU No. 2/1989 tentang Sistem Pendidikan Nasional belum disahkan (dalam tahap pembahasan di DPR-RI). Hasil-hasil kajian merekomendasikan bahwa SLTP Kejuruan perlu diubah menjadi SLTP Umun. Alasannya antara lain adalah kenyataannya sebagian besar ST dan SKKP tetap melanjutkan ke SLTA (khususnya SLTA Kejuruan) dan mereka belum cukup umur untuk bekerja. ${ }^{55}$

Mengembangkan Institusi Pasangan (industri dan perusahaan) untuk menjamin sustainabilitas financial (financial sustainability) dan relevansi serta ukuran keberhasilan sekolah menengah kejuruan. Pengembangan Sekolah Seutuhnya (PSS) atau Integrated School Development (ISD). Melalui program ini, program SMK disesuaikan dengan konteks lingkungan. Kemahiran tenaga dikembangkan dengan

\footnotetext{
${ }^{53}$ Ibid., hlm. 94-95

${ }^{54}$ Ibid., hlm. 96-97

55Ibid., hlm. 98-99
} 
bantuan tenaga dari PPPG lingkup kejuruan yang diterjunkan ke lokasi sekolah. Menindaklanjuti implikasi dari disahkannya UU No. 2/1989 tentang Sistem Pendidikan Nasional, antara lain dengan mengalihfungsikan 187 SLTP Kejuruan (ST dan SKKP) dari 274 SLTPK yang ada saat itu. Menambah dan mengembangkan 47 SMKTA yang meliputi pendirian 20 SMKTA baru, penegerian 5 SMKTA Swasta, dan alih fungsi 22 SPG/SGO menjadi SMKTA. Meningkatkan mutu 30.811 guru sekolah kejuruan melalui berbagai penataran. Melanjutkan pembangunan PPPG Teknologi Malang dan meningkatkan peran dan fungsi PPPG yang telah ada, serta melengkapi sarana BLPT. Benny Suprapto Brotosiswojo merupakan salah satu Guru Besar ITB (1981-sekarang), pernah menjabat sebagai Direktur Dikmenum (19761988), Direktur Dikmenjur (1988-1992), Rektor Universitas Terbuka (1992-1996), dan Rektor Universitas Katolik Parahyangan Bandung. ${ }^{56}$

Mengimplementasikan Kurikulum SMK tahun 1984 dan merevisinya menjadi Kurikulum SMK 1996-1998. Menjabarkan kebijakan "Link \& Match" ke dalam program-program pendidikan kejuruan dengan tujuan agar proses, program, dan hasil pendidikan SMK lebih sesuai dengan kebutuhan dunia usaha dan industri. Mendifusikan perubahan orientasi dalam pengelolaan pendidikan kejuruan yang meliputi 10 butir, antara lain perubahan dari supply-driven ke demand-driven, pengembangan program berbasis kompetensi, menghilangkan sekat yang memisahkan sekolah dan dunia usaha/ industri, menggagas sistem multi-entry-exit dan sertifikasi kompetensi, serta menggalakan Unit Produksi. Mengembangkan Pendidikan Sistem Ganda (PSG) di SMK dengan melibatkan belasan ribu industri/perusahaan sebagai institusi pasangan yang mewadahi 409.734 siswa. Merestrukturisasi organisasi Direktorat Dikmenjur dengan diadakannya Subdit Pembinaan PSG. Memulai pelaksanaan Lomba Keterampilan/Kompetensi Siswa (LKS) SMK, melakukan acara "Gebyar SMK", memfasilitasi Pokja Pengembangan Pendidikan dan Pelatihan Kejuruan di Indonesia yang menghasilkan laporan “Keterampilan Menjelang 2020” (1997). Dalam kurun waktu 1994-1998, siswa SMK naik dari 1,47 juta menjadi 2,0 juta. Mengembangkan dan mengimplementasikan program keterampilan pada ratusan SLTP yang meliputi 8 bidang keterampilan. Drs.

${ }^{56}$ Ibid., hlm. 100-101 
Jorlin Pakpahan pernah menjabat sebagai staf Pembantu Pimpinan pada Direktorat Pendidikan Teknologi Depdikbud (1969-1973), Kasi Sarana dan Prasarana Direktorat Dikmenjur (1973-1975), Kasubdit PTP (1976-1983), Kepala PPPG Teknologi Bandung (1980-1992), Direktur Dikmenjur (1992- 1998), Sekjen ATEA (ASEAN Technician Education Association) (1982), Sekjen Majelis Pendidikan Kejuruan Nasional (1994- 1998), Governing Board Member SEAMEO VOCTECH, Brunei Darrussalam (1996-1998), Resource Member, Colombo Plan Staff Collage for Technician Education, Manila (1994-1999). Mengikuti berbagai pelatihan di dalam dan luar negeri (1976- 1995), serta menjabat Ketua Yayasan EL-EM di Jakarta. ${ }^{57}$

Merevisi dokumen "Pendidikan Kejuruan Menjelang 2020" untuk memungkinkan SMK lebih fleksibel dan permeabel selaras dengan semangat reformasi dan otonomi daerah. Menegaskan SMK bukan lagi hanya sebagai "pendidikan kejuruan" melainkan lembaga "Diklat Kejuruan" atau Pusat Pendidikan dan Pelatihan Kejuruan Terpadu (PPKT). Mengubah pengelolaan Diklat kejuruan dan terpusat menjadi lebih terdesentralisasi. Memprakarsai perubahan dari pendekatan pembelajaran berbasis kompetensi (competence-based learning/curriculum). Menata ulang bidang/program keahlian di SMK sebagai PPKT. Skenario makro tersebut dituangkan dalam dokumen "Reposisi Pendidikan Kejuruan Menjelang 2020”. Menggagas berdirinya Badan Nasional Standarisasi/Sertifikasi Profesi (BNSP) yang dilengkapi Lembaga Sertifikasi Profesi (LSP). Mengembangkan kurikulum kecakapan hidup (life skills). Memprakarsai pembaruan Kurikulum SMK tahun 1999 dan melakukan kajian-kajian bagi pembaruan kurikulum berikutnya. Dr. Ir. Gatot Hari Priowirjanto mengajar sebagai Dosen ITB (1977-sekarang) untuk matakuliah Bahan Galian Industri dan Kristal Optik (1978-1980), Geoteknik (1986-1990), Hidrogeologi, Simulasi Data, Pemetaan Air Tanah, Teknik Pemboran, Hidrogeologi Lanjut, dan Manajemen Air Tanah (1986-1996). Asisten Umum Lembaga Penelitian ITB (1989- 1995), Asisten Direktur Bidang Kemahasiswaan dan Kerjasama Program Pascasarjana ITB (1990-1996) Atase Pendidikan dan Kebudayaan di KBRI Bonn, Jerman (1996-1998), Direktur

${ }^{57}$ Ibid., hlm. 102-103 
SEAMEO SEAMOLEC, Jakarta - Indonesia (2007-2015), kini menjabat sebagai Direktur SEAMEO Secretariat, Bangkok - Thailand (2015-2019). ${ }^{58}$

Program utamanya adalah meningkatkan keterampilan siswa SMK melalui pembuatan dan perakitan peralatan praktek sendiri sesuai dengan kompetensi keahlian siswa yang relevan, antara lain pada bidang teknologi, pertanian dan manufaktur. Membuka unit-unit produksi yang berlokasi di sekolah sebagai inkubator bisnis untuk menumbuhkan jiwa wirausaha warga sekolah. Memperkuat tata kelola SMK melalui penerapan sistem manajemen mutu berbasis ISO 9001:2008. Melaksanakan program rintisan "Wajib Belajar" 12 tahun dengan langkah awal mengubah Biaya Operasional Manajemen Mutu (BOMM) menjadi Rintisan Biaya Operasional Sekolah (BOS). Serta menciptakan citra baik SMK yang disosialisasikan kepada seluruh elemen masyarakat Indonesia melalui berbagai media komunikasi dengan tujuan agar masyarakat dapat mengetahui perkembangan tingkat kinerja yang dicapai $\mathrm{SMK} .{ }^{59}$

Kebijakan yang dilakukan adalah meletakan dasar sistem Teknologi Informasi dan Komunikasi bagi pengelolaan SMK. Mengembangkan pembelajaran yang tidak hanya pembalajaran klasikal tetapi juga memanfaatkan teknologi yang terkini yaitu menggunakan e-learning. ${ }^{60}$

Kebijakan yang dilakukan adalah berpijak pada gagasan nawacita Presiden Jokowi pada poin ke lima yaitu; "meningkatkan kualitas hidup manusia" dan poin ke enam yaitu; "meningkatkan produktivitas rakyat dan daya saing di pasar internasional". Strategi yang dilakukan adalah dengan membuat pemetaan SMK seIndonesia dalam program Verifikasi Wilayah (Verwil). Data yang muncul pada Verwil ini kemudian dianalisa menjadi informasi dasar untuk pengambilan intervensi kebijakan. Sehingga program-program utama yang diterapkan adalah sebagai berikut: ${ }^{61}$

\footnotetext{
${ }^{58}$ Ibid., hlm. 104-105

${ }^{59}$ Ibid., hlm. 106-107

${ }^{60}$ Ibid., hlm. 108

${ }^{61}$ Ibid., hlm. 110-111
} 
1) Menyukseskan pelaksanaan Kartu Indonesia Pintar. Tujuan yang akan dicapai melalui strategi ini adalah meningkatkan jumlah dan kualitas peserta didik SMK.

2) Afirmasi khusus pada daerah 3T. Program yang ditujukan untuk meningkatkan kapasitas SMK yang berada di berada di Provinsi Papua dan Papua Barat, berada di Daerah Khusus, dan berada di Daerah yang tergolong Tertinggal, Terluar, Terdepan (3T).

3) Memfokuskan pengembangan SMK Bidang Keahlian Perikanan dan Kelautan, Pertanian, dan Pariwisata.

4) Pemenuhan Guru Produktif melalui: a) kolaborasi dengan Lembaga Pendidik dan Tenaga Kependidikan; b) Pengadaan Guru Produktif oleh Pemerintah (Pusat+Daerah); dan c) Recognition Prior Learning (RPL).

5) Peningkatan sistem tata kelola yang transparan dan akuntabel dengan melibatkan publik. Arah kebijakan yang diterapkan dalam melaksanakan tujuan strategis ini melalui: a). Pengelolaan data pokok pendidikan menengah kejuruan b). Perencanaan, pemantauan dan evaluasi pelaksanaan program dan kinerja lembaga c). Penyediaan layanan informasi kebijakan d). Pengembangan e-Bantuan. Implementasi e-bantuan SMK untuk proses penyaluran bantuan dan pelaporannya dengan melibatkan ekosistem sekolah, disdik prov/kab/kota dan masyarakat.

6) Penyesuaian bidang keahlian/program studi keahlian dengan kebutuhan global dengan memperhatikan keseimbangan hard dan soft skill.

7) Program SMK Berbasis Industri/Keunggulan Wilayah berfungsi sebagai pusat pengembangan unit Teaching Factory, SMK Rujukan, MKPI.

Memasuki era Masyarakat Ekonomi Asean (MEA) yang sudah dimulai pada akhir tahun 2015 dan menghadapi perdagangan bebas untuk kawasan Asia Pasifik (APEC) diperlukan usaha peningkatan kompetensi tenaga kerja agar dapat meninggikan mutu dan ragam produk yang dapat bersaing di pasar bebas. Dalam kaitan tersebut, diperlukan Sekolah Menengah Kejuruan yang handal dan mampu menerapkan prinsip Total Quality Management (TQM) agar dapat menjawab tantangan permasalahan ketenagakerjaan. Hal ini penting karena tujuan utama sistem 
pendidikan kejuruanadalah mempersiapkan peserta didik terutama untuk bekerja dalam bidang tertentu. Sehingga diharapkan tamatannya menjadi tenaga kerja produktif, mampu meningkatkan pendapatan dan taraf hidup serta dapat mengembangkan dirinya dalam menghadapi perubahan yang semakin cepat. Indonesia memiliki potensi yang sangat besar untuk tumbuh dan berkembang menjadi bangsa yang sejahtera. Di samping sumber daya alamnya yang kaya, Indonesia memiliki tenaga kerja dalam jumlah yang berlimpah. Agar potensi tersebut dapat menjadi sumber daya pembangunan, diperlukan pendidikan yang bermutu dan relevan. Sejalan dengan itu, keterlibatan dunia kerja, khususnya dunia usaha/industri, harus terus dikembangkan dalam penerapan kebijakan pengelolaan sistem pendidikan kejuruan. Pelaksanaan Pendidikan Sistem Ganda (PSG) sebagai implementasi dari kebijakan Link \& Match merupakan bukti adanya keterlibatan aktif pihak dunia usaha/ industri dalam pengelolaan pendidikan kejuruan. ${ }^{62}$

Paradigma program pendidikan kejuruan menjelang tahun 2020 menekankan pada perubahan-perubahan mendasar, antara lain sebagai berikut: ${ }^{63}$

a) Orientasi pendidikan kejuruan dikembangkan dari supply-driven ke demanddriven.

b) Sistem pengelolaan pendidikan kejuruan berubah dari terpusat menjadi terdesentralisasi pendekatan pembelajaran Pendidikan kejuruan bergeser dari pendekatan mata pelajaran menjadi pendekatan pembelajaran berbasis kompetensi (CBT).

c) Pola penyelenggaraan pendidikan kejuruan yang sangat terstruktur menjadi lebih fleksibel dan permeable.

\section{Aktivis Kerja Sekolah Kejuruan Menurut Ekonomi Syariah}

Setelah penulis paparkan sejarah kedua lembaga kejuruan tersebut, maka jika ditinjau dari ekonomi Islam, kemungkinan besar bahwa MAK akan lebih sesuai dengan prinsip-prinsip ekonomi Islam, sebab di MAK pelajaran agama sebanyak 70 $\%$ dibandingkan dengan SMK yang hanya $30 \%$. Namun jika ditinjau dari keahlian 
dan kejuruan pada dua lembaga tersebut, seolah SMK lebih berkopeten dan lebih pakar daripada di MAK, sebab di SMK jam kejuruan 70\% dan jam pelajaran agama hanya 30\%. Dari kedua lembaga kejuruan tersebut pada dasarnya bisa disesuaikan, misalnya SMK memang jam belajar keahlian lebih banyak sedangakn jam belajar agama lebih sedikit, tapi jam agama bisa ditambah dirumah dan dilingkungan masyarakat, sehingga hasilnya akan seimbang antara ilmu kejuruan dengan ilmu agama. Sebaliknya demikian juga MAK yang jam belajar agama lebih banyak dibandingkan jam kejuruan, namun hal tersebut dapat dikejar dengan praktek lapangan dan belajar secara otodidak, sehingga kedua mata pelajaran tersebut akan seimbang juga. Untuk lebih jelasnya maka akan penulis paparkan besaran manfaat kedua lembaga kejuruan tersebut.

Pertama-tama kita harus mengetahui apa itu MAK atau Madrasah Aliyah Kejuruan. Madrasah Aliyah Kejuruan yang disingkat MAK merupakan madrasah atau sekolah bernuansa Islam yang bernaung di bawah kementerian agama seperti halnya madrasah-madrasah lainnya (bagi MAK Negeri), bedanya MAK ini menggunakan materi-materi kejuruan seperti halnya di SMK. Terlebih pemerintah kini sangat memberikan perhatian cukup besar terhadap SMK karena dapat menghasilkan output langsung kerja sehingga siswa-siswa lulusan sekolah kejuruan memiliki ketrampilan tersendiri yang dapat mengurangi prosentase pengangguran di negara kita. ${ }^{64}$

Sebenarnya MAK dan SMK sama-sama sekolah kejuruan, tetapi ada perbedaan yang sangat mendasar dari kedua sekolah itu. Sama-sama kejuruan boleh saja, bahkan output siswanya sama-sama memiliki keterampilan namun materi atau subtansi mapelnya lebih sempurna MAK. Mengapa dikatakan sempurna? Karena secara teori dan akal, materi yang diajarkan oleh madrasah mengacu pada bobot mapel PAI (Pendidikan Agama Islam) yang banyak sehingga tidak hanya mampu menguasai materi umum saja tetapi juga materi agama, mengingat madrasah akan membawa para siswa selamat di dunia dan akhirat. ${ }^{65}$

\footnotetext{
${ }^{64}$ Noor Wahidah A.W, “Keunggulan Madrasah Aliyah Kejuruan yang Bikin Iri?”, Kompasiana, (9 April 2016), https://www.kompasiana.com/noorwahidah93/5708efa03dafbd99092355f8/keunggulan-madrasahaliyah-kejuruan-yang-bikin-iri, diakses 3 Juli 2019. ${ }^{65}$ Ibid.
} 
MAK hampir sama dengan SMK, di MAK akan diajarkan materi-materi ketrampilan-ketrampilan yang ada di sekolah kejuruan, sehingga MAK merupakan sekolah atau madrasah idaman yang dapat menghantarkan kita dalam mencapai kesuksesan dunia dan akhirat. Kesuksesan dunia didapat dari materi umum dan kejuruan sehingga outputnya siswa sukses mendapatkan pekerjaan sesuai dengan kemajuan zaman saat ini dan dapat mengurangi prosentase pengangguran di negara ini. Sedangkan kesuksesan akhirat didapat dari materi PAI sehingga outputnya siswa paham akan agama, mengamalkannya dan dijamin selamat di dunia dan akhirat. ${ }^{66}$

Gak ada ruginya belajar di MAK, kurang apa coba Madrasah Aliyah Kejuruan ini? Harusnya sekolah lain merasa iri dengan subtansi dari MAK ini. Meskipun memang sekolah kejuruan dianggap sebelah mata oleh sebagian masyarakat. Itu dikarenakan mereka tidak melihat ada apa di dalamnya, terlebih MAK ini memang masih tidak sepopuler MA maupun SMA yang sudah banyak dikenal oleh orang banyak. $^{67}$

Sebagai masyarakat sebaiknya pemerintah bersama masyarakat mulai mengunggulkan madrasah ini dan lebih memperhatikan MAK ini kalau tidak ingin mempertinggi angka prosentase pengangguran. Padahal penyebab pengangguran ini ialah banyaknya masyarakat yang lebih memilihkan sekolah anak di sekolah umum dan madrasah yang favorite bukan di kejuruan. Padahal lulusan SMA maupun MA yang hanya bukan program keterampilan, akan sulit mengikuti perkembangan zaman sekarang ini. Karena orang pintar tanpa keterampilan apapun maka akan sulit mencari pekerjaan. Semoga bermanfaat dan terima kasih. ${ }^{68}$

Dari paparan diatas, maka dapat diambil pelajaran, bahwa dari dua lembaga kejuruan tersebut, yaitu MAK dan SMK, jika ditinjau dari prinsip-prinsip ekonomi Islam yang lebih mengarah ke penguatan ajaran agama, sehingga bisa diamalkan dan diaplikasikan dalam dunia kerja setelah lulus MAK dan SMK, maka menurut penulis MAK lebih relevan dan lebih menguntungkan, baik dunia maupun akhirat. Apalagi jika ditimbang dengan teori filsafat pendidikan dan pendidikan Islam yang berorientasi pada budi pekerti yang luhur dan berakhlakul karimah, maka tujuan 
pendidikan MAK persepktif ekonomi Islam lebih mendekati sempurna diabandingkan SMK.

\section{KESIMPULAN}

Dari sejarah dan asal muasal serta perjalanan panjang MAK dan SMK, maka dapat disimpulkan bahwa MAK lebih berorientasi pada pendidikan agama yang berbasis skill atau keterampilan sebagai bekal menjalani hidup di dunia. Sedangkan SMK hampir dipastikan lebih menonjolkan skill dan ketetampilan saja, sedikit ditambah pemanis pelajaran agama sebagai penyeimbang antara dunia dan akhirat. Muatan-muatan mata ajar dari kedua lembaga kejuruan tersebut, hampir bertolak belakang, MAK 70\% mata ajar agama, SMK 70\% mata ajar kejuruan. Maka hampir dipastikan dari kedua alumni MAK dan SMK yang kecenderungan akan belajar ekonomi Islam atau kuliah jurusan ekonomi Syariah adalah MAK. Dari dua lembaga kejuruan tersebut, yaitu MAK dan SMK, jika ditinjau dari prinsip-prinsip ekonomi Islam yang lebih mengarah ke penguatan ajaran agama, sehingga bisa diamalkan dan diaplikasikan dalam dunia kerja setelah lulus MAK dan SMK, maka menurut penulis MAK lebih relevan dan lebih menguntungkan, baik dunia maupun akhirat. Apalagi jika ditimbang dengan teori filsafat pendidikan dan pendidikan Islam yang berorientasi pada budi pekerti yang luhur dan berakhlakul karimah, maka tujuan pendidikan MAK persepktif ekonomi Islam lebih mendekati sempurna diabandingkan SMK

\section{DAFTAR PUSTAKA}

Asari, Hasan, Menyingkap Zaman Keemasan Islam; Kajian atas Lembaga-Lembaga Pendidikan (Bandung: Mizan, 1994).

Assegaf, Abdurahman, Politik Pendidikan Nasional; Pergeseran Kebijakan Pendidikan Agama Islam dari Praproklamasi ke Reformasi (Yogyakarta: Kalam Mulia, 2005).

Azra, Azyumardi, Paradigma Baru Pendidikan Nasional; Rekonstruksi dan Demokratisasi (Jakarta : Kompas, 2002).

Azra, Azyumardi, Pendidikan Islam; Tradisi dan Modernisasi Menuju Millenium Baru (Jakarta: Logos, 1999). 
Daulay, Haidar Putra, Historisitas dan Eksistensi Pesantren Sekolah dan Madrasah (Yogyakarta: Tiara Wacana, 2001).

Departemen Agama RI, Al-Qur'an dan Terjemahanya (Semarang: Toha Putra, 2015).

Depertemen Pendidikan dan Kebudayaan, Kamus Besar Bahasa Indonesia (Jakarta: Kemendikbud, 2010).

Djumhur, dan Danasuparta, Sedjarah Pendidikan (Bandung Djakarta: Tjerdas, 1961).

Fadjar, A. Malik, Madarsah dan Tantangan Modernitas (Bandung : Mizan, 1999).

Harun, "Mengenal Madrasah Aliyah (MA) Dan (MAK)", barunarcom.blogspot.com, (4 Juli 2019), http://harunarcom.blogspot.com/2014/06/mengenal-madrasahaliyah-ma-dan-mak.html, diakses 3 Juli 2019.

Ihsan, Fuad, Dasar-Dasar Kependidikan (Jakarta : PT. Rineka Cipta, 2008)

Khurniawan, Arie Wibowo, dkk., SMK: Sekolah Menengah Kejuruan dari Masa ke Masa (Jakarta: Direktorat Jenderal Pendidikan Dasar dan Menengah Kementerian Pendidikan dan Kebudayaan Republik Indonesia Kompleks Kementerian Pendidikan dan Kebudayaan RI, 2016/2018).

Kosim, Mohammad, "Madrasah Di Indonesia (Pertumbuhan dan Perkembangan)", Jurnal Tadris, Vo. 2. No 1. (2007), 41-57.

Lembaran Negara Undang-Undang Republik Indonesia Nomor 20 Tahun 2003 Tentang Sistem Pendidikan Nasional Pasal 1 ayat 1, 1-26.

Listiara, Anita dan Asmadi Alsa, "Esensi Bersekolah bagi Siswa Berisiko di Sekolah Menengah Kejuruan (SMK)”, Jurnal Psikologi, Vol. 38, No. 2, (2011), 164175.

Makdisi, George, The Rise of Colleges: Institutions of Learning in Islam and The West (Edinburg : Edinburg University Press, 1981).

Maknun, Johar, "Pengembangan Sekolah Menengah Kejuruan (SMK) Boarding School Berbasis Keungulan Lokal", Direktori/FPTK/Jurusan Pendidikan Teknik. Arsitektur, (Upi Edu: 196803081993031), 1-30.

Maksum, Madrasab; Sejarah dan Perkembangannya (Jakarta: Logos, 1999).

Mohammad, Ardiyan, "Sistem Pendidikan Biang Kerok Indonesia Minimnya Wirausaha", Merdeka.com, (12 Juli 2014), https://www.merdeka.com/uang/sistem-pendidikan-biang-kerok-indonesiaminim-wirausaha.html, diakses 3 Juli 2019.

Mukhtar, Muh. Ali dan Jejen Musfah, "Membangun Kewirausahaan di Sekolah". Journal for Integrative Islamic Studies Hikmatuna, Vo. 4 No. 2 (2018), 204-215.

Muslim, Novriza bin, "Riwayat Sekolah Menengah Kejuruan", Novrizalbinmuslim.wordpress.com, (1 Oktober 2014), https:/ / novrizalbinmuslim.wordpress.com/2014/10/01/riwayat-sekolahmenengah-kejuruan/, diakses 4 Juli 2019.

Peraturan Menteri Agama RI Nomor 60 tahun 2015 tentang Perubahan atas Peraturan Menteri Agama RI Nomor 90 tahun 2013 tentang Penyelenggaraan Pendidikan Madsrasah. 
Pramono, Yoga, "Kajian Kebutuhan dan Penyediaan Sekolah Menengah Kejuruan di Kabupaten Rembang", Tesis Master (Semarang: Program Pasca Sarjana Magister Teknik Pembangunan Wilayah dan Kota Universitas Diponegoro, 2009).

Saefudin, Agus, Smk: Sekolah Mencetak Kuli dan Pengangguran (Sebuah Kritik dan Solusi Arah Kebijakan Sekolah Menengah Kejuruan), Makalah Master (Semarang: Program Pascasarjana Program Studi Manajemen Pedidikan Konsentrasi Kepengawasan Sekolah Universitas Negeri, 2015).

Salinan Menteri Pendidikan Nasional Nomor 28 Tahun 2009 Tentang Standar Kompetensi Kejuruan Sekolah Menengah Kejuruan (SMK)/Madrasah Aliyah Kejuruan (MAK).

Salinan Peraturan Menteri Pendidikan Pendidikan dan Kebudayaan Republik Indonesia Nomor 70 Tahun 2013 Tentang Kerangka Dasar dan Struktur Kurikulum Sekolah Menengah Kejuruan/Madrasah Aliyah Kejuruan.

Setiawan, Yuli, "Mengenal Sejarah Pendidikan Kejuruan di Indonesia", Psmk.kemdikbud.go.id, (31 Mei 2016), http://psmk.kemdikbud.go.id/konten/1614/mengenal-sejarah-pendidikankejuruan-di-indonesia, diakses 4 Juli 2019.

SK Mendikbud ini dikeluarkan sebagai tindak lanjut dari PP Nomor 29/1990 tentang Pendidikan Menengah, 1-20.

SK Mendikbud Nomor 489/U/1992 selanjutnya ditindaklanjuti dengan Keputusan Menteri Agama Nomor 370/1993 tentang Madrasah Aliyah, 1-17.

Steenbrink, Karel A., Pesantren Madrasah Sekolah; Pendidikan Islam dalam Kurun Moderen (Jakarta: LP3ES, 1994).

Syalabi, Ahmad, Sedjarah Pendidikan Islam, terj. Muchtar Jahja dan Sanusi Latief (Jakarta: Bulan Bintang, 1973).

Syamsudini, H M., "Pendidikan Madrasah Dalam Lintas Sejarah Indonesia", Jurnal Turats, (36.91.149.11), 145-152.

Wahidah, Noor, A.W, "Keunggulan Madrasah Aliyah Kejuruan yang Bikin Iri?”, Kompasiana, (9 April 2016), https://www.kompasiana.com/noorwahidah93/5708efa03dafbd99092355f8 /keunggulan-madrasah-aliyah-kejuruan-yang-bikin-iri, diakses 3 Juli 2019.

Walfajri, Maizal dan Herlina Kartika, "Menkop UKM : Rasio wirausaha Indonesia sudah lebih dari 7\%". Kontan.co.id, (05 Juni 2018), https://peluangusaha.kontan.co.id/news/menkop-ukm-rasio-wirausahaindonesia-sudah-lebih-dari-7, diakses 3 Juli 2019.

Walfajri, Maizal dan Narita. "Jumlah pelaku UMKM di 2018 diprediksi mencapai 58,97 juta orang", Kontan.co.id, (05 Oktober 2018), https://keuangan.kontan.co.id/news/jumlah-pelaku-umkm-di-2018diprediksi-mencapai-5897-juta-orang, diakses 3 Juli 2019. 